\title{
First Polish records of Myxomycetes rare in Europe
}

\author{
Anna Bochynek* \\ Institute of Botany, Jagiellonian University, Kopernika 31, 31-501 Cracow, Poland
}

\begin{abstract}
Seven species of Myxomycetes are reported from Poland for the first time. These are Arcyria virescens, Cribraria costata, $C$. elegans, C. languescens, C. mirabilis, C. pertenuis and Trichia flavicoma. They have very few localities in Europe and Cribraria pertenuis is known only from two sites worldwide. The species are described and illustrated with microphotographs, including first published micrographs of $C$. pertenuis. Localities are given and the taxonomy and ecology of each species are discussed.
\end{abstract}

Keywords: Myxomycetes; taxonomy; distribution; new records; Poland; Europe

\section{Introduction}

Only approximately 250 species of Myxomycetes (Myxogastria) have been noted from Poland until the present moment [1]. Investigations were conducted by the author in the Niepołomice Primeval Forest, a remaining part of an old-growth forest in southern Poland (Małopolska Province). The majority of the forest complex is commercially managed by the State Forests National Forest Holding. The average altitude is 210 meters above sea level. In total, the forest area covers 10924 ha and is divided into 403 forest sections (Fig. 1). It comprises six forest reserves (Dębina, Długosz Królewski, Gibiel, Koło, Lipówka and Wiślisko Kobyle). Pinus sylvestris is the main stand-forming tree species dominating in more than $61 \%$ of the forest. Quercus robur, which predominates in $19.2 \%$ of the area, is the second most important tree species [2].

\section{Material and methods}

The material was collected by the author during the 2010-2012 spring-autumn seasons in the Niepołomice Primeval Forest. Specimens were collected both in commercially managed forest areas (below: NF-section number) and protected sites (below: R-section number and the name of the reserve).

All microscopic measurements were taken with $100 \times$ magnification using an immersion objective. Spore diameter was measured together with the spore wall ornamentation. Laboratory examinations were conducted using a ZEISS Axioskop 2 plus light microscope. Microphotographs were

\footnotetext{
*Email: annabochynek@gmail.com
}

Handling Editor: Beata Zagórska-Marek taken using a Nikon D7000 digital camera and a Nikon H600L microscope.

Specimens and microscope slides are deposited in the Herbarium Universitatis Iagellonicae Cracoviensis (KRA) in the MYXO division.

The nomenclature was accepted after Lado (2005-2015) [3].

\section{Results and discussion}

\section{Arcyria virescens G. Lister Fig. 2d-f}

DIAGNOSTIC CHARACTERS. Sporocarps in broad groups, ochraceous yellow to greenish yellow. Stalks single or 2-4 adherent, 0.7-1.2 mm long (Fig. 2e). Calyculus slender, funnel-shaped, inner surface with a network of ridges (Fig. 2d). Capillitium elastic, threads 5-6 $\mu \mathrm{m}$ wide, strongly decorated with groups of rings, half-rings and reticulate lines (Fig. 2f). Spores globose, 9.5-10 $\mu \mathrm{m}$.

DISTRIBUTION IN EUROPE. It has been reported only from France [4].

SPECIMENS EXAMINED. On dead wood of Quercus robur, R-255 Dębina, 2010.10.26, KRAMYXO 6122.

\section{Cribraria costata Dhillon \& Nann.-Bremek. Fig. 3a,b}

DIAGNOSTIC CHARACTERS. Sporocarps in groups, ochraceous yellow to ochraceous brown. Sporotheca globose 0.4-0.6 mm diam. Stalks slender, hollow, longitudinally plicate, granular between the plicae, 1.6-2.2 mm long. Peridial cup reduced to $1 / 5$ of the sporotheca and remaining between the ribs of which 24-35 radiate from the apex of the stalk and reach halfway up the sporangium (Fig. 3a). Calcic granules 


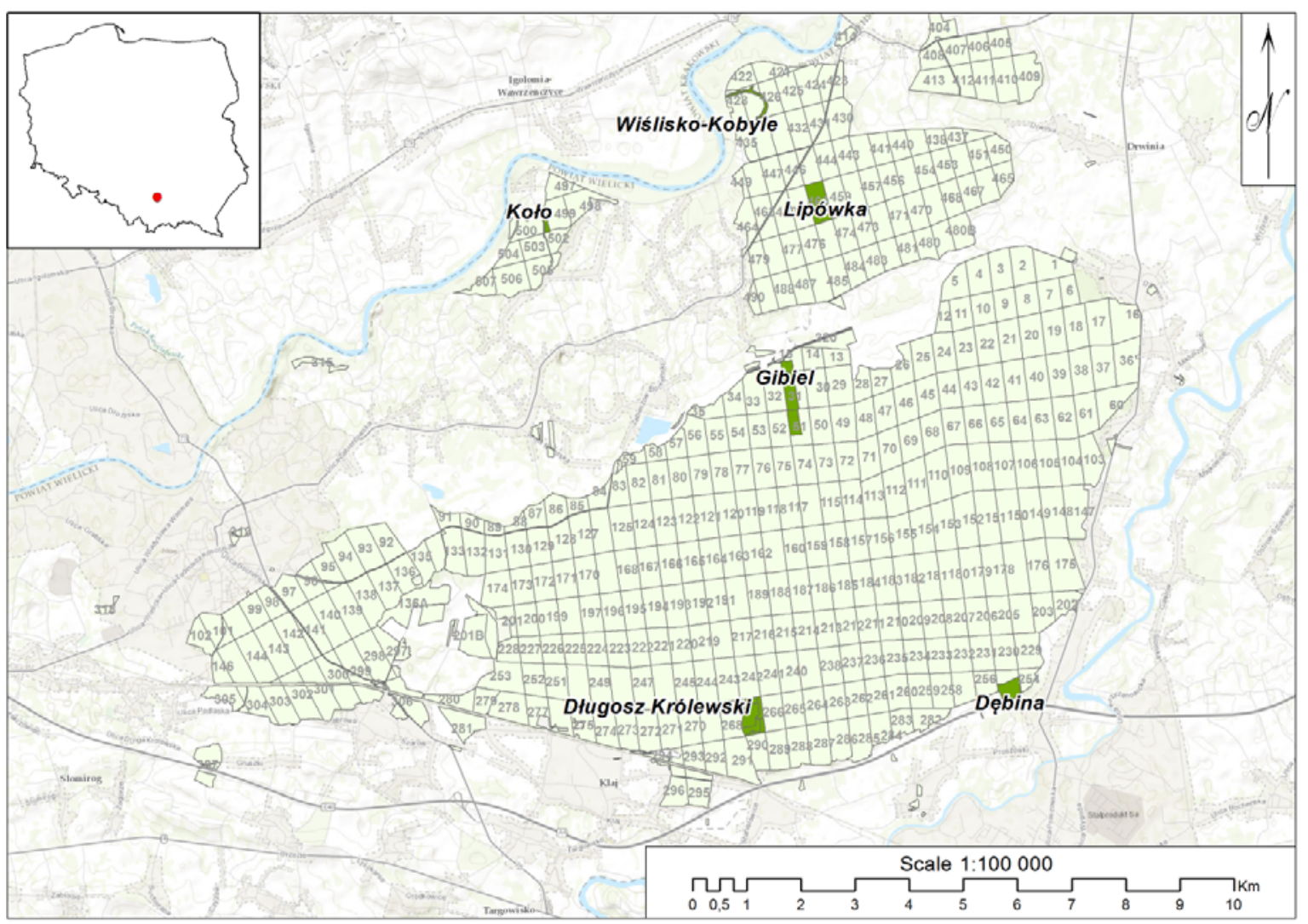

Fig. 1 Situation of the study area with forest section numbers and the names of the nature reserves.

$1.5-2.5 \mu \mathrm{m}$. Nodes of the peridial net numerous, pulvinate, irregular, rounded, elongate and angular (Fig. 3b). Spores pale, minutely warted, $6.0-7.0 \mu \mathrm{m}$.

NOTES. This specimen was found in association with sporocarps of Cribraria piriformis.

DISTRIBUTION IN EUROPE. It has been reported only from France and Germany $[4,5]$.

SPECIMENS EXAMINED. On dead wood of Pinus sylvestris, NF-270, 2010.08.19, KRA MYXO 6120.

\section{Cribraria elegans Berk. \& M.A. Curtis Fig. 3c,d}

DIAGNOSTIC CHARACTERS. Sporocarps loosely gregarious, dark purplish-brown, shining. Sporotheca globose $0.3-0.45 \mathrm{~mm}$ diam. Stalks slender, furrowed, 0.7-1.3 mm long. Peridial cup occupying $1 / 2$ of the sporotheca, concentrically plicate and filled with dark calcic granules concentrated especially along the cup margin and arranged as lines radiating from the stalk (Fig. 3c). Calcic granules dark, 1.5-2 $\mu \mathrm{m}$. Nodes of the peridial net expanded, flat, polygonal and scarcely thickened (Fig. 3d). Spores globose, $6.5-8.0 \mu \mathrm{m}$.

NOTES. Similar to the specimens recorded in a study by Adamonyte and Eliasson [6], margins of nodes forming the sporothecal net were very often distinctly darker than their centers (KRAMYXO 6124; see Fig. 3d) and lighter purplish red calcic granules were observed in some sporotheca (KRAMYXO 4605) in the material collected by me.

These specimens were found in association with sporocarps of Cribraria pertenuis, C. intricata and Stemonitis axifera.

DISTRIBUTION IN EUROPE. It has been reported only from France and Austria [5,7].

SPECIMENS EXAMINED. On dead wood of Pinus sylvestris, NF-209, 2010.08.13, KRAMYXO 4605; R-267 Długosz Królewski, 2011.07.23, KRA MYXO 6124.

\section{Cribraria languescens Rex Fig. 3e,f}

DIAGNOSTIC CHARACTERS. Sporocarps in groups, coppery brown to dark purplish brown (Fig. 3e). Sporotheca globose $0.3-0.4 \mathrm{~mm}$ diam. Stalks slender, tenuous, $1.8-2.5 \mathrm{~mm}$ long. Peridial cup occupying $1 / 3-1 / 2$ of the sporotheca, somewhat shiny, finely ribbed and dotted with calcic granules; usually thickened at the rim (Fig. 3f). Calcic granules $1.5-2 \mu \mathrm{m}$, pale violet to purplish brown. Nodes of the peridial net thickened, rather flat and angular, with few free ends. Spores pale, globose, minutely warted, 6.5-7.0 $\mu \mathrm{m}$.

NOTES. These specimens were found in association with sporocarps of Cribraria cancellata, C. pertenuis and C. vulgaris. 


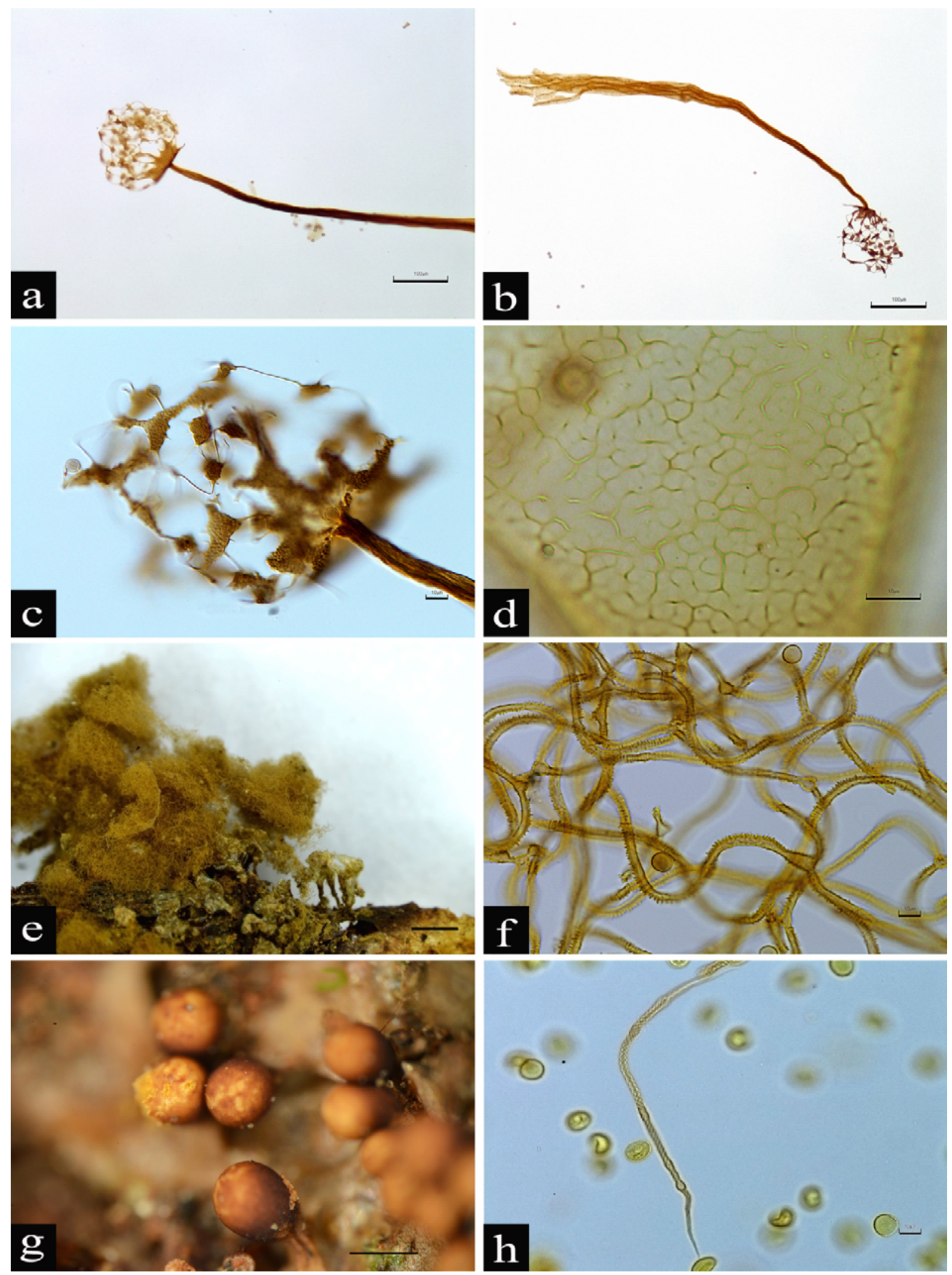

Fig. 2 Morphological and anatomical characters of examined specimens. a-c Cribraria pertenuis: (a) sporocarp (KRA MYXO 4603), (b) sporocarp (KRA MYXO 6116), (c) sporocarp (KRA MYXO 6135). d-f Arcyria virescens (KRA MYXO 6122): (d) the inner surface of the calyculus, (e) sporocarps, (f) capillitium and spores. g,h Trichia flavicoma (KRA MYXO 6137): (g) sporocarps, (h) elaters and spores. Scale bars: a,b $100 \mu \mathrm{m} ; \mathbf{c}, \mathbf{d}, \mathbf{f}, \mathbf{h} 10 \mu \mathrm{m} ; \mathbf{e}, \mathbf{g} 1 \mathrm{~mm}$. 

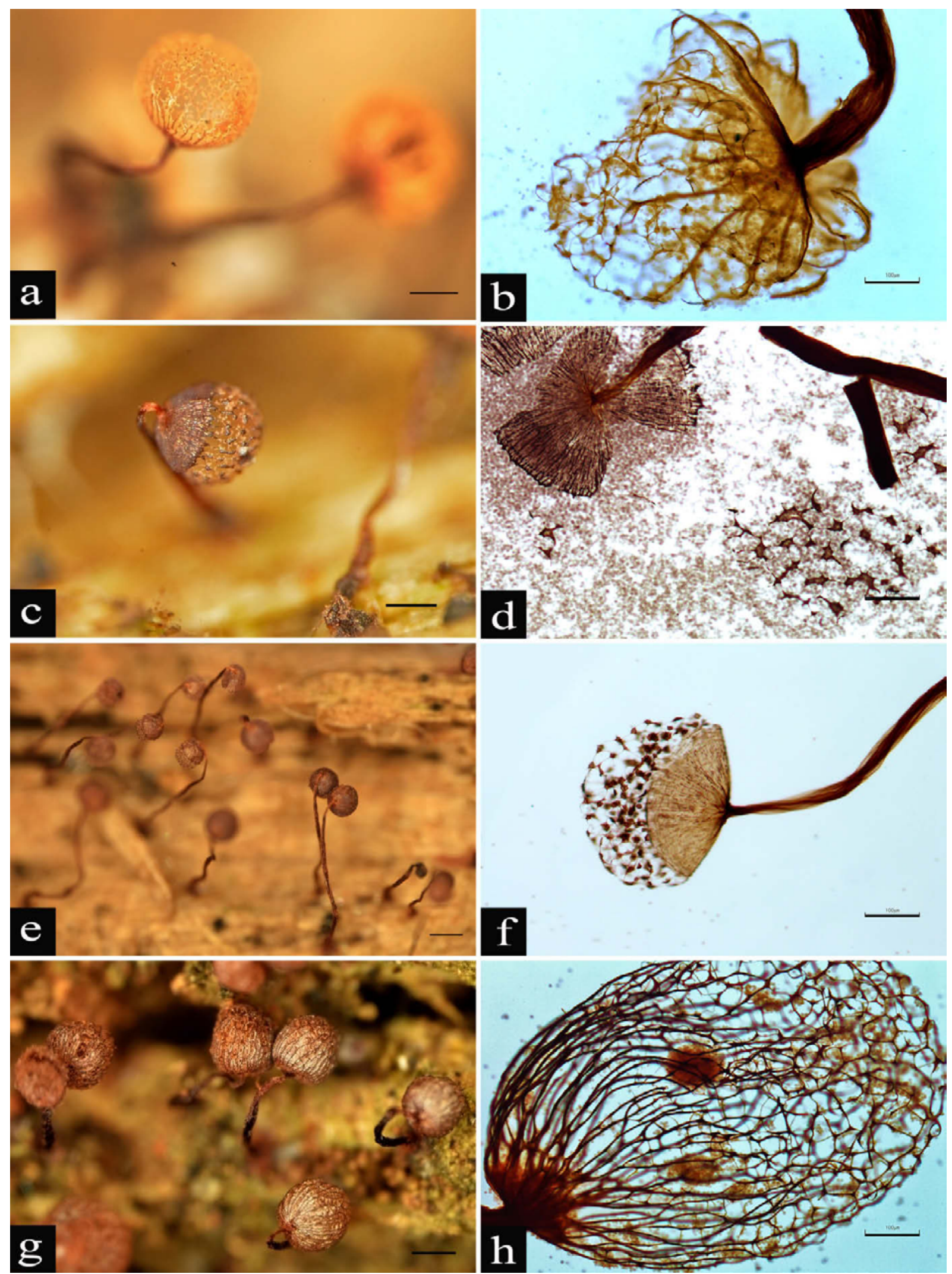

Fig. 3 Morphological and anatomical characters of examined specimens. a,b Cribraria costata (KRA MYXO 6120): (a) sporocarps, (b) sporocarp. c,d C. elegans: (c) sporocarp (KRA MYXO 4605), (d) fragment of the peridial cup and peridial net (KRA MYXO 6124). e,f C. languescens (KRA MYXO 5172): (e) sporocarps, (f) sporocarp. g,h C. mirabilis (KRA MYXO 6126): (g) sporocarps, (h) sporocarp. Scale bars: a $0.25 \mathrm{~mm}$; b,d,f,h $100 \mu \mathrm{m} ; \mathbf{c} 0.2 \mathrm{~mm}$; e,g $0.5 \mathrm{~mm}$. 
DISTRIBUTION IN EUROPE. It has been recorded only in a few European countries such as France, Germany, Hungary and Russia $[4,5,8,9]$.

SPECIMENS EXAMINED. On dead wood of Pinus sylvestris; NF-253, 2010.07.23, KRA MYXO 5172; NF-9, 2011.08.19, KRA MYXO 6131; NF-22, 2011.08.19, KRA MYXO 5688.

\section{Cribraria mirabilis (Rostaf.) Massee Fig. 3g,h}

DIAGNOSTIC CHARACTERS. Sporocarps in large groups, purple-brown to dark purple. Sporotheca globose or subglobose, iridescent, 0.6-0.8 mm diam (Fig. 3g). Stalks grooved, 0.9-1.3 mm long. Peridial net consisting of iridescent membranes between 28-41 thickened ribs reaching from the base to over half way up the sporangium and giving rise to a net without widened nodes (Fig. 3h). Calcic granules dark, 1-1.5 $\mu \mathrm{m}$. Spores pale, globose, minutely warted, 6-7 $\mu \mathrm{m}$, often bearing calcic granules.

DISTRIBUTION IN EUROPE. It has been recorded only in a few European countries such as France, Germany, Ireland, Italy, Netherlands, Spain and Sweden [4,5,10-13].

SPECIMENS EXAMINED. On dead wood of Pinus sylvestris; NF-122, 2011.07.16, KRA MYXO 6126; NF-123, 2011.07.16, KRA MYXO 6125.

\section{Cribraria pertenuis Flatau \& Schirmer Fig. 2a-c}

DIAGNOSTIC CHARACTERS. Sporocarps scattered, pale violet to pale brown. Sporotheca globose, $0.10-0.18 \mathrm{~mm}$ diam. Stalks slender, tenuous, $0.5-0.8 \mathrm{~mm}$ long. Peridial cup star-shaped, occupying 1/5-1/4 of the sporotheca and sometimes with deep irregular teeth (Fig. 2a-c). Peridial net with few meshes. Nodes flat and polyhedric, with very few free ends (Fig. 2c). Calcic granules 1.5-2.5 $\mu \mathrm{m}$. Spores globose, pale violet to pale brown, minutely warted with some larger warts, 7-8 $\mu \mathrm{m}$.

NOTES. The species may resemble Cribraria macrostipitata and C. stellifera, which are also small-sized; however, they differ by thickened net nodes with more numerous free ends. The former has longer stalks, 3-5 $\mathrm{mm}$ in length, while the latter has densely packed and larger calcic granules, 3-4 $\mu \mathrm{m}$ in size $[5,14]$.

Since as many as ten localities of the species were recorded in three vegetative seasons, $C$. pertenuis may not be such an exceptionally rare species. The scarcity of literature reports

\section{Acknowledgments}

The author is grateful to Dr. Anna Drozdowicz for valuable consultations in species identification, to Mrs. Marianne Meyer for the information and photographs regarding French specimens of Cribraria pertenuis. This research was supported by the Institute of Botany, Jagiellonian University (decision No. K/DSC/000/160).

\section{Competing interests}

No competing interests have been declared. concerning this slime mould may be related to the lack of its descriptions in popular determination keys to Myxomycetes published prior to $2011[5,12,13,15]$.

These specimens were found in association with sporocarps of: Ceratiomyxa fruticulosa, Cribraria argillacea, C. cancellata, C. elegans, C. languescens, C. microcarpa, C. persoonii, C. vulgaris and Stemonitis axifera.

GENERAL DISTRIBUTION. Published data regarding the species is available only from Germany and France $[4,15]$.

SPECIMENS EXAMINED. On dead wood of Quercus robur, R-255 Dębina, 2010.07.16, KRAMYXO 6116, 2010.07.16 KRAMYXO 6117; on dead wood of Carpinus betulus, R-499 Koło, 2010.08.14, KRAMYXO 6121; on dead wood of Tilia sp., R-460 Lipówka, 2011.08.03, KRAMYXO 6127; on dead wood of Pinus sylvestris, R-267 Długosz Królewski, 2010.08.12, KRA MYXO 6119, 2012.06.21, KRA MYXO 6133; NF-10, 2011.08.19, KRA MYXO 6130; NF-179, 2012.08.22, KRA MYXO 6135; NF-209, 2010.08.13, KRA MYXO 4603; NF-253, 2010.07.23, KRA MYXO 6118.

\section{Trichia flavicoma (Lister) Ing Fig. 2g,h}

DIAGNOSTIC CHARACTERS. Sporocarps ovoid, gregarious, ochraceous brown marked with a reticulum of yellow lines, $0.3-0.4 \mathrm{~mm}$ diam (Fig. 2g). Stalks single or adherent, $0.2-0.3 \mathrm{~mm}$ long. Capillitium made of free ochraceous yellow threads. Elaters $4.5-5 \mu \mathrm{m}$ wide, smooth, often with swellings, free ends pointed, 35-45 $\mu \mathrm{m}$ long (Fig. 2h). Spores globose, minutely warted, $11-13 \mu \mathrm{m}$.

NOTES. In taxonomic studies, Trichia flavicoma is reported as a species occurring only on dead leaves and litter. This is one of the features that distinguish it from T. subfusca, which is associated with dead wood and should have short, often bent elater ends $(12-20 \mu \mathrm{m})[4,5,12,13]$. However, $T$. flavicoma has recently been reported to occur also on dead wood [16-18] as recorded at the Polish locality. As the specimens are morphologically strictly consistent with the description of T. flavicoma, the species may have a broader microhabitat range than reported previously.

DISTRIBUTION IN EUROPE. It has been reported from Portugal, Spain, France, Ukraine, Great Britain, Netherlands, Germany, Lithuania and Russia $[4,5,11-13,16,17,19,20]$.

SPECIMENS EXAMINED. On dead wood of Quercus robur, R-51 Gibiel, 2012.10.12, KRA MYXO 6137.

\section{References}

1. Drozdowicz A, Ronikier A, Stojanowska W, Panek E, editors. Myxomycetes of Poland - a checklist. Kraków: W. Szafer Institute of Botany, Polish Academy of Sciences; 2003. (Biodiversity of Poland; vol 10).

2. Wimmer W, Buczak J, Stec S, Młynarczyk B. Monografia Nadleśnictwa Niepołomice. Niepołomice: Nadleśnictwo Niepołomice; 2006.

3. Lado C. An on line nomenclatural information system of Eumycetozoa [Internet]. 2005-2015 [cited 2015 Dec 3]; Available from: http://www. eumycetozoa.com 
4. Poulain M, Meyer M, Bozonnet J. Les Myxomycetes. Guide de détermination. 1. Sevrier: Editepar la Fédération mycologique el botanique Dauphiné-Savoie; 2011.

5. Neubert H, Nowotny W, Baumann K. Die Myxomyceten Deutschlands und des angrenzenden Alpenraumes unter besonderer Berücksichtigung Österreichs. Bd. 1. Ceratiomyxales, Echinosteliales, Liceales, Trichiales. Gomaringen: Karlheinz Baumann Verlag; 1993.

6. Adamonyte G, Eliasson UH. Morphological variation and taxonomic characters in Cribraria (Myxomycetes) from the Great Smoky Mountains National Park in eastern USA. Nova Hedwigia. 2010;90:303-320. http://dx.doi.org/10.1127/0029-5035/2010/0090-0303

7. Mitchell DW, Nannenga-Bremekamp NE. Myxomycetes collected in France and preserved in our private collections. Proc K Ned Akad Wet C. 1976;79(4):381-392.

8. Revay A. Review of the Myxomycetes of Hungary. Stud Bot Hung. 2008;39:5-20.

9. Novozhilov YK, Zemlianskaia IV, Schnittler M, Stephenson SL. Myxomycete diversity and ecology in the arid regions of the Lower Volga River Basin (Russia). Fungal Divers. 2006;23:193-241.

10. Nannenga-Bremekamp NE. An annotated list of Myxomycetes found in The Netherlands. Additions and emendations I. Acta Botanica Neerlandica. 1962;11:35-36. http://dx.doi.org/10.1111/j.1438-8677.1962. tb00072.x

11. Lado C, Pando F. Myxomycetes I. Ceratiomyxales, Echinosteliales, Liceales, Trichiales. Madrid: Borntraeger; 1997. (Flora Mycologica Iberica; vol 2).
12. Ing B. The Myxomycetes of Britain and Ireland. An identification book. Slough: The Richmond Publishing Co.; 1999.

13. Nannenga-Bremekamp NE. A Guide to temperate Myxomycetes. Bristol: Biopress Ltd.; 1991.

14. Neubert H, Nannenga-Bremekamp NE. Drei neue Arten aus der Klasse Myxomycetes. Zeitschrift für Pilzkunde. 1977;43:237-243.

15. Flatau L, Schirmer P. Neue Myxomyceten-Funde in Nordhessen und Deutschland. Z Mykol. 1994;60(1):253-274.

16. Leontyev DV, Dudka IO, Kochergina AV, Kryvomaz TI. New and rare Myxomycetes of Ukraine. 3. Forest and foreststeppe zone. Nova Hedwigia. 2012;94:335-354. http://dx.doi. org/10.1127/0029-5035/2012/0005

17. Novozhilov YK, Schnittler M, Vlasenko AV, Fefelov KA. Myxomycete diversity of the Altay Mountains (southwestern Siberia, Russia). Mycotaxon. 2010;111:91-94. http://dx.doi.org/10.5248/111.91

18. Wrigley de Basanta D, Lado C, Estrada-Torres A, Stephenson SL. Biodiversity of myxomycetes in subantarctic forests of Patagonia and Tierra del Fuego, Argentina. Nova Hedwigia. 2010;90:45-79. http:// dx.doi.org/10.1127/0029-5035/2010/0090-0045

19. Stephenson SL, Novozhilov YK, Schnittler M. Distribution and ecology of myxomycetes in highlatitude regions of the Northern Hemisphere. J Biogeogr. 2000;27:741-754. http://dx.doi. org/10.1046/j.1365-2699.2000.00442.x

20. Kutorga E, Adamonytė G, Iršènaitè R, Kasparavičius J, Markovskaja S, Motiejūnaitė J, et al. A checklist of mycobiota recorded in burnt and unburnt Pinus mugo plantations in the Curonian Spit (Lithuania). Bot Lith. 2012;18(1):66-79. http://dx.doi.org/10.2478/v10279-012-0009-3 